\title{
Summary of Carbon Storage Project Public Information Meeting and Open House, Hawesville, Kentucky, October 28, 2010 \\ Topical Report
}

December 8, 2009, through June 25, 2012

David C. Harris, David A. Williams, J. Richard Bowersox Kentucky Geological Survey, 228 Mining and Mineral Resources Bldg., University of Kentucky, Lexington, KY 40506-0107

Report Issued: June 25, 2012

\begin{abstract}
Report Number: DOE/FE0002068-2
U.S. DOE Cooperative Agreement Number: DE-FE0002068 An Evaluation of the Carbon Sequestration Potential of the Cambro-Ordovician Strata of the Illinois and Michigan Basins
\end{abstract}

Principal Investigator: Dr. Hannes Leetaru Business Contact: Illinois State Geological Survey

615 E. Peabody Drive Champaign, IL 61820-7406 
This report was prepared as an account of work sponsored by an agency of the United States Government. Neither the United States Government nor any agency thereof, nor any of their employees, makes any warranty, express or implied, or assumes any legal liability or responsibility for the accuracy, completeness, or usefulness of any information, apparatus, product, or process disclosed, or represents that its use would not infringe privately owned rights. Reference herein to any specific commercial product, process, or service by trade name, trademark, manufacturer, or otherwise does not necessarily constitute or imply its endorsement, recommendation, or favoring by the United States Government or any agency thereof. The views and opinions of authors expressed herein do not necessarily state or reflect those of the United States Government or any agency thereof. 


\title{
Task 3.9: Summary of Carbon Storage Project Public Information Meeting and Open House, Hawesville, Kentucky, October 28, 2010
}

\author{
David C. Harris, \\ David A. Williams \\ J. Richard Bowersox \\ Kentucky Geological Survey, University of Kentucky, Lexington, KY 40506
}

\begin{abstract}
The Kentucky Geological Survey (KGS) completed a second phase of carbon dioxide $\left(\mathrm{CO}_{2}\right)$ injection and seismic imaging in the Knox Group, a Cambrian-Ordovician dolomite and sandstone sequence in September 2010. This work completed 2 years of activity at the KGS No. 1 Marvin Blan well in Hancock County, Kentucky. The well was drilled in 2009 by a consortium of State and industry partners (Kentucky Consortium for Carbon Storage). An initial phase of $\mathrm{CO}_{2}$ injection occurred immediately after completion of the well in 2009. The second phase of injection and seismic work was completed in September 2010 as part of a U.S. DOE-funded project, after which the Blan well was plugged and abandoned.

Following completion of research at the Blan well, a final public meeting and open house was held in Hancock County on October 28, 2010. This meeting followed one public meeting held prior to drilling of the well, and two on-site visits during drilling (one for news media, and one for school teachers). The goal of the final public meeting was to present the results of the project to the public, answer questions, and address any concerns. Despite diligent efforts to publicize the final meeting, it was poorly attended by the general public. Several local county officials and members of the news media attended, but only one person from the general public showed up. We attribute the lack of interest in the results of the project to several factors. First, the project went as planned, with no problems or incidents that affected the local residents. The fact that KGS fulfilled the promises it made at the beginning of the project satisfied residents, and they felt no need to attend the meeting. Second, Hancock County is largely rural, and the technical details of carbon sequestration were not of interest to many people. The county officials attending were an exception; they clearly realized the importance of the project in future economic development for the county.
\end{abstract}

Recommended best practices resulting from this public meeting are:

- Start outreach and communications early, and continue through completion of the project

- Follow through on initial plans and promises: Do what you said you were going to do

- Keep the outreach process open and transparent 


\section{Table of Contents}

$\begin{array}{ll}\text { Executive Summary } & \text { p. } 4 \\ \text { Objectives } & \text { p. } 5 \\ \text { Introduction and Background } & \text { p. } 5 \\ \text { Planning, Organization, and Publicity } & \text { p. } 5 \\ \text { Meeting Location and Date } & \text { p. } 5 \\ \text { Pre-Meeting Publicity } & \text { p. } 6 \\ \text { Meeting Agenda } & \text { p. } 6 \\ \text { Results and Discussion } & \text { p. } 8 \\ \text { Attendance } & \text { p. } 8 \\ \text { Key Issues Raised } & \text { p. } 8 \\ \text { Results and Impact } & \text { p. } 8 \\ \text { Conclusions } & \text { p. } 9 \\ \text { Lessons Learned and Best Practices } & \text { p. } 9 \\ \text { Appendix: Photographs and Press Coverage } & \text { p. } 11\end{array}$

\section{Executive Summary}

The Kentucky Geological Survey and industry partners drilled an 8,126-ft-deep carbon storage research well in Hancock County, Kentucky, in 2009. Two phases of injection tests in the Knox Group carbonates and Gunter Sandstone were completed, including both brine and carbon dioxide injection. The second phase of injection was completed in September 2010 as part of U.S. DOE Cooperative Agreement DEFE0002068, An Evaluation of the Carbon Sequestration Potential of the Cambro-Ordovician Strata of the Illinois and Michigan Basins. Subtask 3.9 of this project was an open house at the conclusion of the project to present results to the public and stakeholders. The open house meeting was held on the evening of October 28, 2010, in Hawesville, Kentucky, at the Hancock County Career Center. Information presented included summaries of the project results by geologists and exhibits of rock core and log data from the well.

Although public attendance at the open house was low, key county government officials were present to hear the results and ask questions about the 2-year-long project. The low turnout was attributed to general satisfaction with how the project was conducted and the lack of problems that affected the public. Specific conclusions and best practices resulting from the open house are:

1. Start outreach and communications early, and continue throughout the project

2. Do what you said you were going to do

3. Keep the research and outreach process open and transparent

4. Emphasize the economic impacts, which are the primary concern to local officials and residents; mitigating climate change is of secondary importance

5. Emphasize both the broader regional impact of the research and the local site-specific benefits (such as site reclamation, road repairs, and improvements to the benefit of the landowner and community) 


\section{Objectives}

A public meeting and open house was held in Hawesville (Hancock County), Kentucky, on October 28, 2010. The goals of this meeting were twofold. First, we wanted to provide an overview and progress report on the regional Knox and St. Peter carbon sequestration research project funded by U.S. DOE under the geological characterization program. The second goal was to communicate to the local community the results of the 2-year-long carbon sequestration research project conducted by the Kentucky Geological Survey in Hancock County.

\section{Introduction and Background}

A public meeting and open house was held in Hawesville (Hancock County), Kentucky, on October 28, 2010. Because much of the public meeting focused on the KGS work in Hancock County, a short history of the KGS project is provided as background. In 2007, State funding was provided to the Kentucky Geological Survey to conduct carbon sequestration demonstration projects in eastern and western Kentucky. An industry-university consortium was formed, the Kentucky Consortium for Carbon Storage (KYCCS) to attract additional industry funding to match the State funds. Strong support from industry dictated that the first demonstration project be done in western Kentucky. Based on regional geology and the project budget, access to a drill site was obtained in Hancock County. After an EPA Underground Injection Control permit was obtained, the Blan No. 1 well was drilled to 8, $126 \mathrm{ft}$ into Precambrian sedimentary rocks. As predicted from seismic data, the Mount Simon Sandstone was absent at this location. Several porous and permeable zones in the Knox were used for injection tests with brine and $\mathrm{CO}_{2}$ in the summer of 2009. A temporary plug was set in the well pending DOE funding for a second phase of testing. After receiving additional funding from DOE, phase 2 tests were designed during the summer of 2010, and conducted in September 2010. Time-lapse vertical seismic profiles were also acquired prior to and following $\mathrm{CO}_{2}$ injection. This work completed the planned research at the Blan well, and it was plugged at the end of September 2010.

Prior to the Hancock County project, KGS received a limited amount of opposition from local residents. County government and officials were supportive of the project, but one or two landowners near the site voiced opposition with KGS and the EPA during our UIC permitting process. The landowner's concerns were deemed unfounded by both EPA and KGS, and they did not impede our progress. We did have some concern that this opposition would be raised again during the open house, but the parties did not attend the meeting.

\section{Planning, Organization, and Publicity}

\section{Meeting Location and Date}

The meeting was held in Hawesville, Kentucky, the county seat of Hancock County, where the injection test project was located. This location was chosen to allow local residents and government officials to attend and hear the results of the project. This fulfilled our promise to the local community to return when the project was complete to present the results. We considered holding the meeting in Owensboro, Kentucky, a larger city about 25 miles to the west, but decided it was more important to keep the meeting in Hancock County. 
The meeting was held at 6 p.m. on October 28,2010 , a Thursday evening. The day and time were chosen to allow people to attend after work and avoid evening activities typically scheduled earlier in the week. The meeting was held in the Hancock County Career Center, a local community employment facility with a training room large enough to accommodate 50 to 60 people for the meeting.

\section{Pre-Meeting Publicity}

Prior to the meeting we publicized the event through a variety of media. Announcements were broadcast or published in the following:

- Hancock County Clarion newspaper: Weekly paper ran front-page story on meeting on Oct. 21, 2010, a full week prior to the meeting (copy provided in appendix)

- Owensboro Messenger-Enquirer ran a story on Oct. 28, the day of the meeting (text included in appendix).

- Electronic announcements were posted to the KGS Web site and to the Kentucky Geologists listserv e-mail distribution.

- E-mail announcements were sent to all project partners and colleagues.

The meeting was at 6 p.m., so refreshments were provided to encourage more attendees to attend, but the dinner hour timing may have hurt attendance.

\section{Meeting Agenda}

The meeting agenda is provided below. The meeting started with refreshments, followed by a time to talk to the Survey staff and view core from the Blan well, posters, and seismic data. Presentations were then made by the principal investigator of the DOE project, Hannes Leetaru (Illinois State Geological Survey) and two KGS researchers, Rick Bowersox and Dave Williams. An interactive demonstration was set up that allowed people to inject air into a core of porous sandstone submerged in water, and contrast it to trying to inject air into a nonporous limestone seal sample. This demonstration was developed by the Midwest Regional Carbon Sequestration Partnership, and has proven very popular at previous KGS outreach events. Various news media were informed of the meeting, and several showed up to cover the event. Presentations were followed by a discussion period. The entire meeting lasted about 90 minutes. 


\section{Carbon Sequestration Public Information Meeting \\ Hancock County Career Center \\ Hawesville, Kentucky \\ October 28, 2010 \\ $\mathrm{CO}_{2}$ Storage Potential of the Cambrian and Ordovician Strata In the Illinois and Michigan Basins}

\section{Funding from:}

U.S. Department of Energy, National Energy Technology Laboratory

Commonwealth of Kentucky, Energy and Environment Cabinet

Western Kentucky Carbon Storage Foundation

Illinois Department of Commerce and Economic Opportunity

\section{Research by:}

Kentucky Geological Survey, University of Kentucky

Sandia Technologies

ConocoPhillips, Peabody Energy, and E.ON US

Illinois State Geological Survey, University of Illinois

Indiana Geological Survey, Indiana University

Western Michigan University

\section{Meeting Agenda}

6:00 p.m. Exhibits, core samples, posters, and refreshments

6:15 p.m. Welcome and introductions, Dave Harris and Jerry Weisenfluh, KGS

6:25 p.m. Overview and results of the Hancock County injection well: Rick Bowersox, KGS

6:50 p.m. Monitoring work and well-site reclamation: Dave Williams, Glynn Beck, KGS

7:00 p.m. DOE Regional Knox and St. Peter Study: Hannes Leetaru, Illinois State Geological Survey

7:25 p.m. Discussion and questions

\section{Internet Resources}

Kentucky Consortium for Carbon Storage:

Knox and St. Peter Sandstone $\mathrm{CO}_{2}$ Project:

Midwest Geological Sequestration Consortium:

Kentucky Geological Survey:

Illinois State Geological Survey:

Indiana Geological Survey:

U.S. DOE Carbon Sequestration: www.kyccs.org

www.knoxstp.org

www.sequestration.org

www.uky.edu/kgs

www.isgs.uiuc.edu

igs.indiana.edu

www.fossil.energy.gov/programs/sequestration 


\section{Results and Discussion}

\section{Attendance}

Based on meetings held prior to and during drilling, and the interest in the project in the local community, we expected an attendance of 40 to 50 people. Attendance fell far below expectations, with a total of 19 people. Of this total, 10 were affiliated with geological surveys involved in the research, and nine were local officials, media, or from the local community. Despite the low turnout, several key local government officials attended, and were actively involved in discussions. The attendees can be broken down into the following groups:

Local county government officials (county judge-executive, magistrates): 4 Director, Hancock County Industrial Foundation: 1 General Public: $\quad 1$ News Media: $\quad 3$

Research team members: $\quad$ Kentucky Geological Survey 8 Illinois State Geological Survey 1 Indiana Geological Survey 1

Total 19

Numerous KGS staff with various areas of expertise attended to answer questions and facilitate discussion. This proved to be a valuable addition to the formal presentations.

\section{Key Issues Raised}

The county judge-executive and magistrates were interested in the presentations, and were satisfied with the way the research and site reclamation and road repairs were done. They were primarily interested in the potential financial impact this research project may have in the future. They wanted to know if having completed this project put Hancock County ahead of other areas in attracting new industry. Other questions concerned the potential for commercial sequestration in Hancock County: how many wells like the Blan well would be needed in a commercial storage field, and what is the worst that could happen if a commercial storage field is developed. County officials also asked if there was an opportunity for the county to run a $\mathrm{CO}_{2}$ storage facility as a service to local businesses (similar to a landfill).

\section{Results and Impact}

This meeting saw low turnout from the general public, but strong interest and attendance from local government officials. We feel adequate advance notice was given, since media and government officials were there. In a small town, largely rural area, local newspaper announcements seemed to be the most effective medium for communication.

The point was made that the initial KGS project had become part of the larger regional DOE-funded Knox/St. Peter project, which helped to emphasize the broader importance of the Hancock County project. 
Results and impact of the meeting are best discussed in terms of the two different groups in attendance: government and general public.

Local Government Officials: Our outreach efforts with the local county government began early in the project, as a site was still being selected. They were kept informed during the 2-year project with a total of six meetings:

- An informal discussion with local officials at a restaurant to present the project idea

- A public meeting at the Hancock County Career Center

- A public meeting in conjunction with a scheduled meeting of the Hancock County Fiscal Court

- A media day with drill-site tour during the drilling phase

- A teacher's day with drill-site tour during the drilling phase

- Final project presentations and DOE project summary at the Hancock County Career Center

KGS kept all promises made to the county officials, including repairs to county roads affected by the project, and covering the county occupation tax incurred by all the out-of-state contractors. This was an important factor in building their confidence in us. We saw a decline in attendance at each of the meetings after the first one. It was particularly interesting that the county officials who attended the meeting seemed much more at ease with what we were doing with each successive meeting (including the site tour). By this meeting, their questions were more educated (a credit to our continued outreach efforts), and they were making observations and asking about the future and about implications of the research. The fact that the local officials and the director of the industrial development foundation recognized the importance of this research to the future of affordable electricity for a major local employer (an aluminum smelter) indicated they are more interested in this work than they originally realized.

Local Resident: We had no local Hancock County residents attend the meeting (other than news media and county officials). Even Mr. Blan, owner of the land where the well was drilled, did not attend. The one person from the general public was from Owensboro, and worked for a pipeline company, and seemed interested in possible new business opportunities resulting from carbon capture and storage.

It was apparent to us that the low turnout was because of the lack of problems during the project, the fact that promises were kept, and because we kept people informed along the way. The fact that the local population was happy with our project resulted in their feeling no need to attend the meeting. They are not interested in the technical details so much as whether there was a major disaster. Beyond the county economic interests represented by the officials that attended, it is hard to get people to care what we did in the absence of some disaster.

\section{Conclusions}

\section{Lessons Learned and Best Practices}

1. Start outreach and communications early, and continue throughout the project.

2. Do what you said you were going to do.

3. Keep the research and outreach process open and transparent.

4. Economic impacts are the primary concern to local officials and residents; mitigating climate change is of secondary importance. 
5. Emphasize both the broader regional impact of the research and the local site-specific benefits (such as site reclamation, road repairs, and improvements to the site and community).

6. Advance notice and free food does not guarantee a good turnout for a public meeting, but ignoring 1, 2, and 3 above will. Poor attendance is often tacit approval that you have done a good job. 


\section{Appendix \\ Photographs and Press Coverage for Hancock County open house}

Meeting photos by Mike Lynch, Kentucky Geological Survey

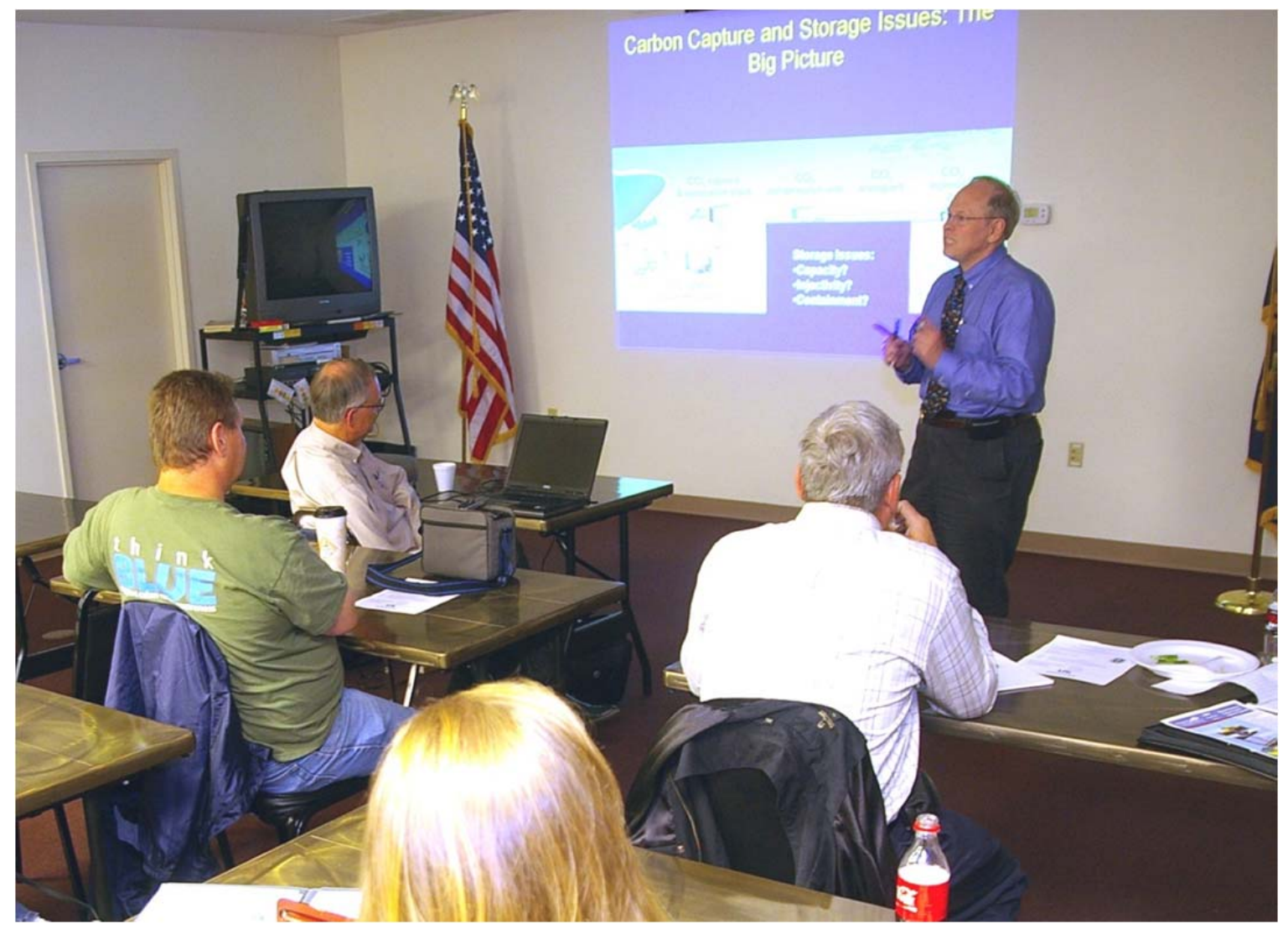

Hannes Leetaru, Illinois State Geological Survey, provided an overview of carbon capture and storage research, and issues in the Illinois Basin. 

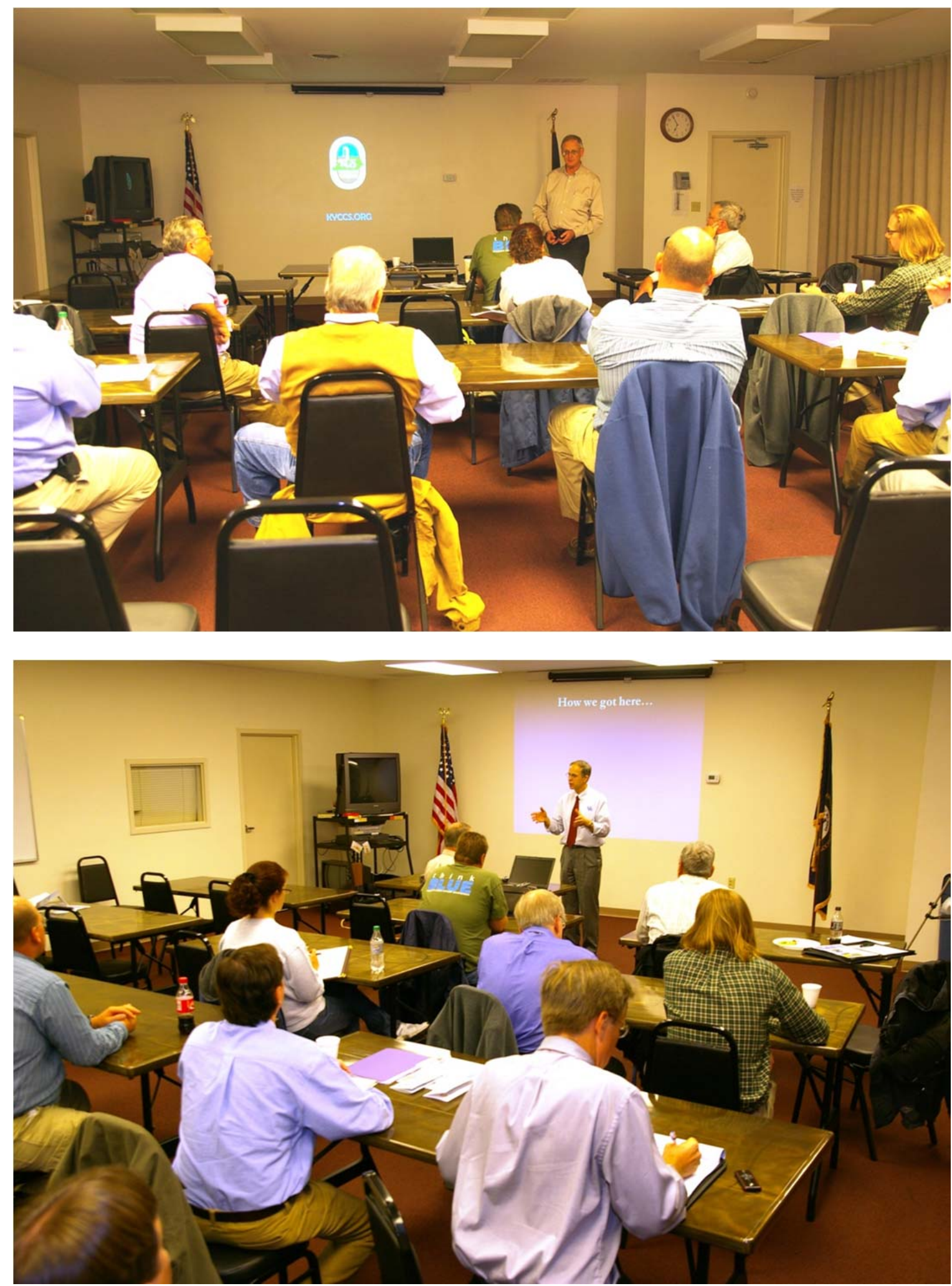

Rick Bowersox (top photo) and Jerry Weisenfluh (bottom photo), both with the Kentucky Geological Survey, presented results of research at the Hancock County deep well at the open house. 


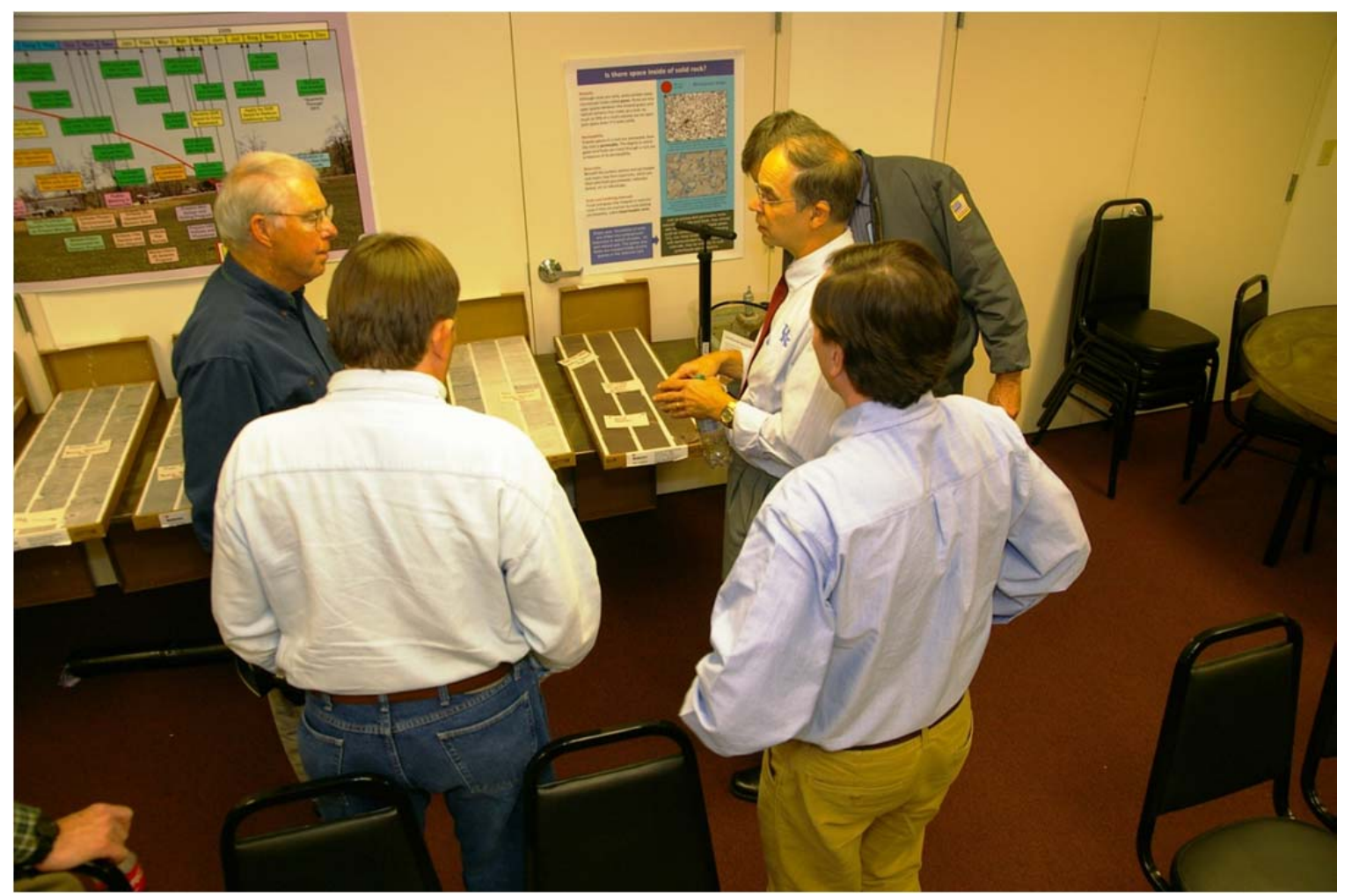

Kentucky Geological Survey staff discussed cores from the KGS No. 1 Blan well that were on display at the open house. 


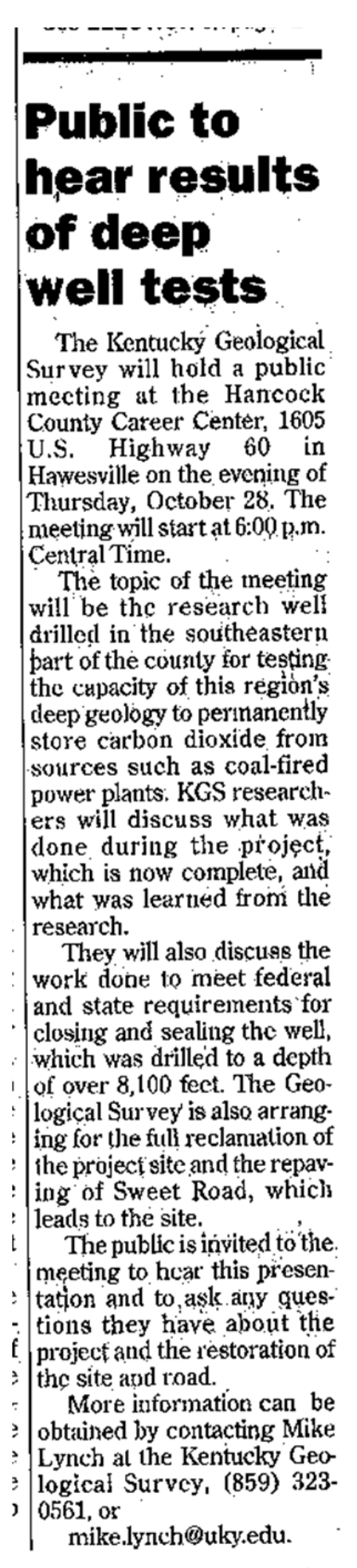

Premeeting announcement published in the Hancock County Clarion newspaper, Oct. 21, 2010. 


\section{Meeting to discuss $\mathrm{CO}_{2}$ test planned for tonight in Hancock}

Thursday, October 28, 2010 4:02 AM

\section{(Source: Owensboro Messenger-Inquirer) By Beth Wilberding, Messenger- Inquirer, Owensboro, Ky.}

Oct. 28--Officials from the Kentucky Geological Survey will discuss the results of a carbon dioxide storage test that began in Hancock County more than a year ago at a public meeting at 6 tonight in Hawesville. The meeting will be at the Hancock County Career Center on U.S. 60. The test well was drilled on a farm in southeastern Hancock County, and researchers are studying whether coalburning plants or other plants that emit carbon dioxide could store their emissions underground. A second round of testing at the site was completed about a month ago. The well has been sealed.

Officials got more focused data in its second round of testing, said Rick Bowersox, a senior research geologist for the Kentucky Geological Survey. "Testing was successful," he said. "We had no trouble injecting it into the formation. All the water went where it was supposed to. All the (carbon dioxide) went where it was supposed to." Researchers pumped 323 tons of carbon dioxide with a water injection into the well in August 2009. At that time, Dave Williams, co-principal investigator for the project, said he was pleased with how the first round of testing went.

Officials tested to see if $\mathrm{CO}_{2}$ could be stored in several different layers of earth. It was injected into an 8,126-foot deep well. The only layer of rock that was found to be viable for the storage was the Knox Group dolomite formation, which is found at depths between 3,800 feet and 7,400 feet. The second round of testing began this summer after officials received a federal grant. The University of Illinois and several of its partners, including the Kentucky Geological Survey, received a \$4.8 million U.S. Department of Energy grant last year from the American Recovery and Reinvestment Act. Researches received better pressure data in the second round of testing because they focused on a very limited test interval, Bowersox said. It gave researchers an idea of what kind of pressure could be injected into the rock, Bowersox said. "The rock is full of water, so you have to overcome the weight of that to inject into it," he said. The geological survey has abandoned the well, and it has been sealed beyond Environmental Protection Agency requirements. The EPA mandates that a well be sealed about 3,660 feet below the surface, and the geological survey has sealed it there and at just above 5,030 feet, Bowersox said.

Researchers are also waiting for the results of a 3-D seismic survey done at the site. Data from the tests will be used in a larger study funded by the Department of Energy that includes the Illinois, Michigan and Indiana geological surveys.

To learn more about the project, visit www.kyccs.org and click on "WKy Deep Test Subproject." Beth Wilberding, 691-7307, bwilberding@messenger-inquirer.com

Text of open house announcement published in the Owensboro Messenger-Enquirer the day of the meeting, Oct. 28, 2010. 


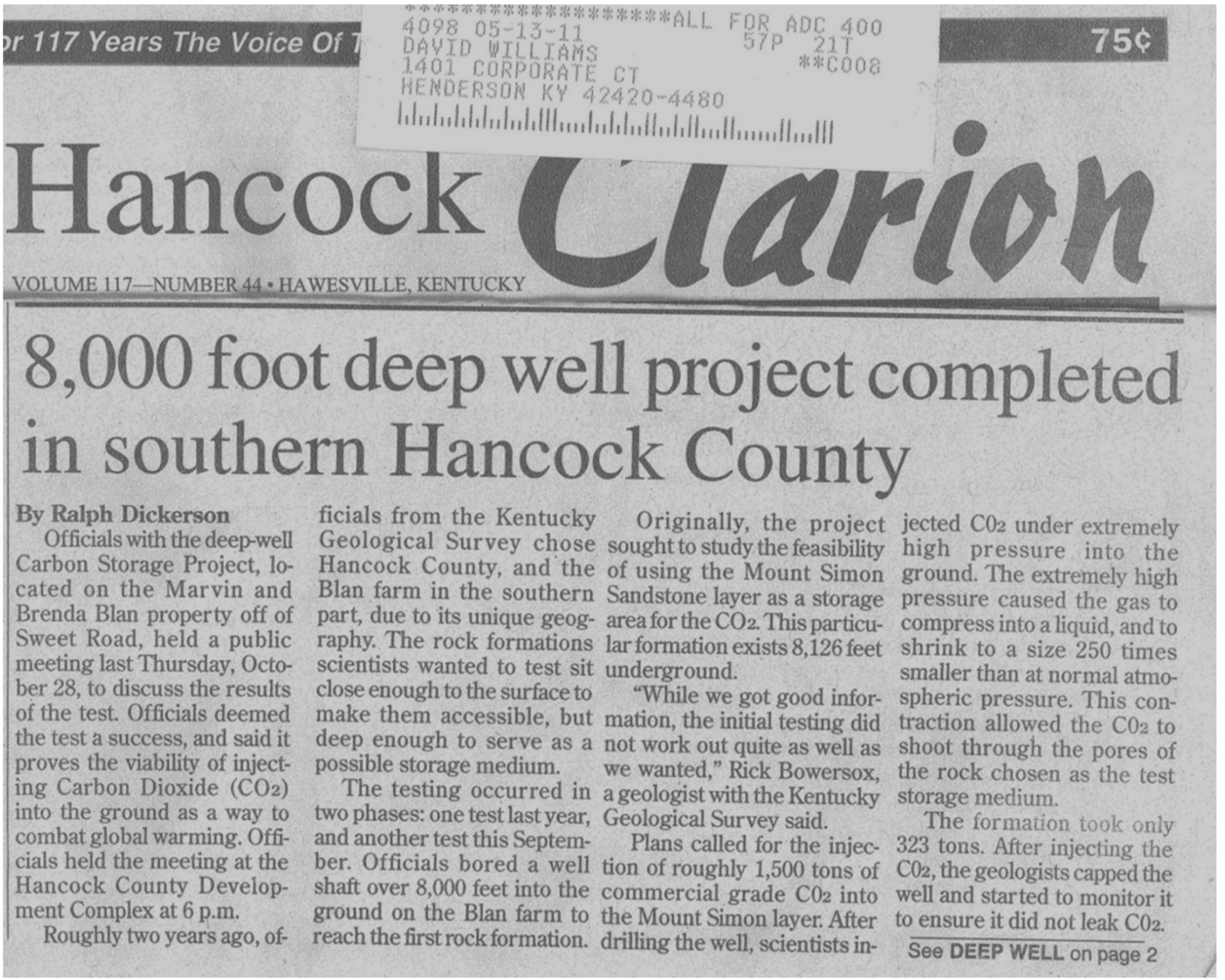

Article published in the Hancock County Clarion on Nov. 11, 2010 after the open-house, summarizing the meeting. 


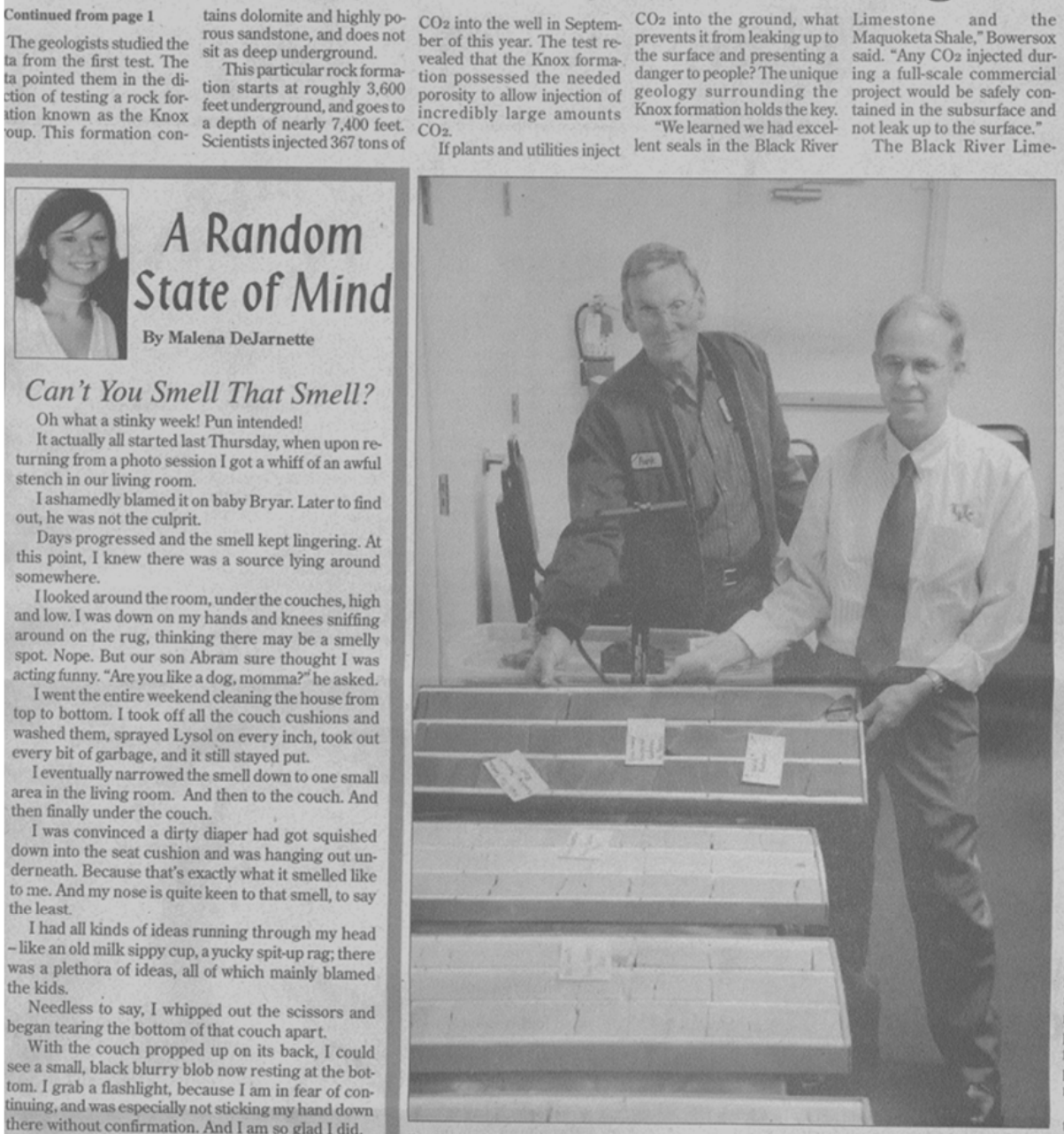

stone and the Maquoket Shale are two formations that sit above the Knox formation. These two features contain extremely dense rock that etrate them, which effectively blocks the upward migration of the gas. Why did geologists want to inject $\mathrm{CO}_{2}$. into the ground? contributes to global warm ing. Power plants and other smoke stack industries dump millions of tons of $\mathrm{CO}_{2}$ into the atmosphere each year due to the use of coal. While other energy sources exist, none of them possess the ability to replace coal as a viable energy source. Scientists seek to find ways to reduce or eliminate the atmosphere from coa fired plants and industries. The question of carbon management is really impor: tant, especially in Kentucky." Jerry Weisenfluh, Associate Director, Kentucky Geological Survey, said. "So much of our electricity is generated by coal."

The test results show that the Western Kentucky Coal Field Region, which includes Hancock County, possesses abundant sites for deep storage wells. The Western Kentucky Coal Field Region sits in a larger formation known as the Ilinois Basis, which ern Indiana and Western Kentucky.

There is a lot of research that needs to be done where and how much, Bowersox said.

Not only did the test prove the viability of storing carbon in the ground, it also provided information on the number of storage wells, and acreage, needed by a commercial power plant over the life of the facility. The average power plant possesses a life-span of We 50 years.

We learned from this well Dr. Jerry Weisenfluh, Associate Director of the Kentucky Geological Survey, right, shows to store 100 - percent of the core samples to Hancock County Magistrate Frank Estes. Weiceal Survey, right, shows $\mathrm{CO}_{2}$ produced by a power taken at the bottom of the well, which reached over 8,000 feet inen the shows the samples plant over the lifetime of the first time anyone has seen core samples from that depth of Hancock County's geology. facility." Bowersox said. "It ouse.

Definitely the cause of the stench. A million questons raced through my mind. How did it get there?

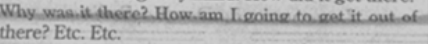

I continue to rip and cut the entire bottom of the couch off. Trust me moms, this is a "need to" task anyway, I found a good handful of toys under there as well. I then ran to the kitchen and grabbed a set of well. Then ran to the kitchen and grabbed a set of tongs. There was no way I was touching this thing
with my bare hands, or a paper towel where I could actually "feel" it.

In the meantime, Abram is saying "cool" and Roven is saying "I scary" (meaning of course he was cared).

I opened the front door and slung the dead rodent put into the woods.

Abram peeks back under the couch and says, "anther mouse momma, get another mouse."

No, there was not another one. But wouldn't that have been a good twist to the story?

I hand-vac'd the far out of that couch. Lysol'd the eeck out of it.....and while doing so I realized that hay have been the murderer of that poor, little baby nouse. Sure, I could have sat on it and flattened it - I zuess. But then I remember that same little mouse ust a week beforehand, peering back at me from be ind the furniture. You certainly don't see adult mice lo this; I knew it was an innocent baby. I tried to shoo t with a broom, but didn't have the heart to hit it. I losed my eyes through half of this process. Maybe I

But all in all, what an odd place for it to be. And vhat an odd thing for me to find.

I thoroughly enjoyed waking up to no smell the I thoroughly

However, my day didn't end so sweet.

However, my day didn't end so sweet.
The "Poop Artist" struck again during nap time.

The "Poop Artist" struck again during nap time.
I opened the door, and the smell just smacked me

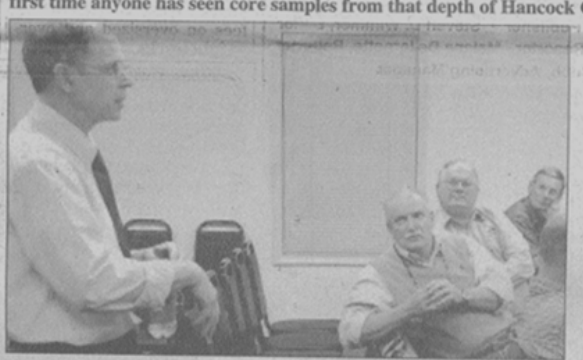

Bowersox said it takes Dr. Weisenfluh years to fill each well, and scianswers a ques. entists envision a continuous tion from the au- injection method to pump the dience as gas underground. Though Hancock County the wells exist only as a small Industrial Foun- hole on the surface, when indation Director jected into the Knox formaMike Baker and tion, the $\mathrm{CO}_{2}$ spreads over an Magistrates area of

Wayne Hodskins ground. Therefore, a facity needs and Frank Estes to purchase up to 350 acres look on. $\quad$ per well. The amount of land needed per well does present an obstacle to overcome. Storing carbon underground presents only one piece of the puzzle in dealing with the issue of global warm ing. The other step is devel. oping cost efficient ways to capture the $\mathrm{CO}_{2}$ from flue gases released when burning According to Brandon Nuttall, a geologist with the Kentucky Geological Survey, ist to capture the $\mathrm{CO}_{2}$, but it takes about 25 to 30 percent of the electrical output of a power plant to operate the equipment. Officials refer to from the electric grid away sitic load.

If utilities retrofit existing

Article published in the Hancock County Clarion on Nov. 11, 2010 after the open-house, summarizing the meeting (continued). 


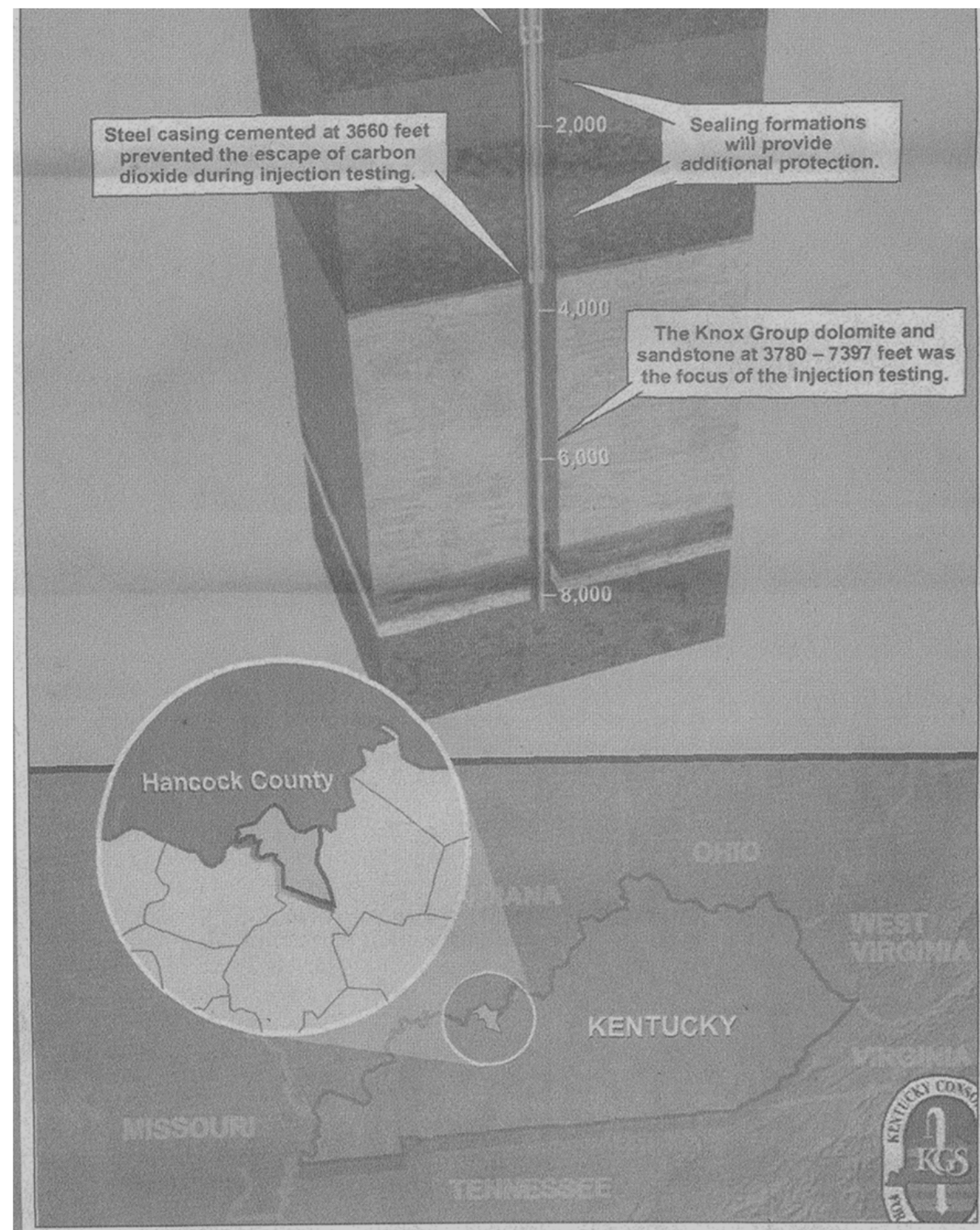

This photo shows a cross section of the formations the project went through, as well as the formation, the Knox Group, that proved successful as a carbon storage medium. ivuttan, a geoiogist witn tne Kentucky Geological Survey, scrubber technology does exist to capture the $\mathrm{CO}_{2}$, but it takes about 25 to 30 -percent of the electrical output of a power plant to operate the equipment. Officials refer to this draining of power away from the electric grid a parasitic load.

If utilities retrofit existing facilities with this technology now, the country needs to increase the number of power plants by the same percentage to generate the same amount of electricity as the current number of facilities produce. Nuttall said the Center for Applied Energy Research at the University of Kentucky seeks to make the technology more efficient.

"They are working to reduce the parasitic load to around 10-percent, " Nuttall said.

At this time officials do not envision carbon capture technology to be implemented for several more years. This project provided the information necessary for projects addressing other issues associated with carbon capture and storage to move for ward.

\section{Community Blood Drive Nov. 13}

Cour tney Haycraft will host her senior project, a community blood drive, at Central Baptist Church in Hawesville. The blood drive will be Saturday, November 13th, from 10:00 a.m. to 2:00 p.m. All donations go to Western Kentucky Regional Blood Center.

Article published in the Hancock County Clarion on Nov. 11, 2010 after the open-house, summarizing the meeting (continued). 